Please quote as: Leimeister, J. M.; Sidiras, P. \& Krcmar, H. (2006): Exploring success factors of virtual communities: The perspectives of members and operators. In: Journal of Organizational Computing \& Electronic Commerce (JoCEC), Ausgabe/Number: 3\&4, Vol. 16, Verlag/Publisher: Lawrence Earlbaum. Erscheinungsjahr/Year: 2006. Seiten/Pages: 277-298. 


\title{
Exploring Success Factors of Virtual Communities: The Perspectives of Members and Operators
}

\author{
Jan Marco Leimeister \\ Pascal Sidiras \\ Helmut Krcmar \\ Information Systems \\ Technische Universitaet Muenchen, Germany
}

\begin{abstract}
Virtual communities have been the focus of research for some time. However, although many studies have provided recommendations on how to build, extend, and manage virtual communities, few have verified the success factors they have considered essential for virtual communities. Conclusions made regarding basic preferences and distinct priorities of different stakeholders in virtual communities have not been empirically substantiated. Building on previous work on success factors of virtual communities, in this article, we present a ranking of success factors discussed in the literature based on an online survey among operators and members of virtual communities in the German speaking Internet. Consequently, we identified and analyzed incongruencies between members and operators. This research gains first empirically validated insights into success factors for establishing and managing virtual communities. We derived recommendations for operators of virtual communities on the basis of the findings, and we present an agenda for future research in the field.
\end{abstract}

virtual communities, success factors, stakeholders of virtual communities, community building, community management, electronic commerce

\section{INTRODUCTION AND REFERENCE FRAMEWORK}

The advent of virtual communities (VC) has concomitantly brought to life a broad field of research during the last few years. Numerous researchers have studied VCs (see, e.g., [1-7] as examples for frequently quoted works), although backgrounds, approaches, and objectives of the studies have differed significantly. Our objective in this research was to evaluate success factors for VCs that have often been postulated in scientific literature and to evaluate their practical importance from the perspective of members and operators of VCs. Based on the evaluation of members and

Correspondence and should be sent to Jan Marco Leimeister, Technische Universität München, Institut für Informatik, Boltzmannstr. 3, 85748 Garching, Germany. Email: leimeister@in.tum.de 
operators, we identified and analyzed deviations. The results provide empirically validated insights into developing, introducing, and managing VCs.

The article is structured as follows. In Section 1, we provide operational definitions and outline the background of the study. We present a set of success factors for VCs as found in the literature and as identified by conducting expert interviews. In Section 2, we describe the methodology used for ranking the success factors. We provide details on data collection in Section 3, and in Section 4, we present the results of the data analysis. We conclude the article with a discussion of the results, and we present a research agenda for the future.

\subsection{VCs}

For various reasons, no common agreement on the definition of the term virtual community can be identified in the literature [8]. First, VCs are a multidimensional research object that can be analyzed from various perspectives including psychology, administrative science, or computer science. The discipline initiating the study tends to define the term VC according to its scientific body of knowledge. Secondly, the phenomenon of popular words, so-called buzz words used in this area, obscures a clear differentiation between scientific terms and jargon [4].

One of the first definitions of VCs proposed by Rheingold [9] in 1993 defined VCs as "social aggregations that emerge from the Net when enough people carry on public discussion long enough, with sufficient human feeling, to form webs of personal relationships in cyber-space" (p. XX). Rheingold [9] characterized VCs as being noncommercial and socially motivated.

Another very often quoted definition of VC, especially in the context of internet euphoria in the mid and late 1990s, was popularized by the former McKinsey Consultants Hagel and Armstrong [10] in their best-selling book Net Gain: Expanding Markets Through Virtual Communities. Hagel and Armstrong [10] defined VCs as

Groups of people with common interests and needs who come together on-line. Most are drawn by the opportunity to share a sense of community with like-minded strangers, regardless of where they live. But virtual communities are more than just a social phenomenon. What starts off as a group drawn together by common interests ends up as a group with a critical mass of purchasing power, partly thanks to the fact that communities allow members to exchange information on such things as a product's price and quality. (p. XX)

This rather economical definition focuses on VCs having a specific area of interest of its members, combining content and different communication possibilities, and having a focus on user-generated content as well as a commercially oriented organization.

As economical or social focuses on VCs hardly do justice to explain all existing types of communities on the Internet, Preece [4] proposed a multidisciplinary approach to understanding VCs. According to Preece's [4] work, a VC

Consists of people, who interact socially as they strive to satisfy their own needs or perform special roles, such as leading or moderating, a shared purpose, such as an interest, need, information exchange, or service that provides a reason for the community, poli- 
cies, in the form of tacit assumptions, rituals, protocols, rules, and laws that guide people's interactions and computer systems, to support and mediate social interaction. (p. $\mathrm{XX)}$

This approach has proven to be very useful because it mentions interacting people, rules of interaction, a common purpose, and a technical platform as constitutive elements. Building on this definition and extending it by the aspects of implicit and explicit rules and the role of the technical platform for building trust and a common identity for its members, we define VCs for this article as follows:

A VC consists of people who interact together socially on a technical platform. The community is built on a common interest, a common problem, or a common task of its members that is pursued on the basis of implicit and explicit codes of behavior. The technical platform enables and supports the community's interaction and helps to build trust and a common feeling among the members.

Similar to the diversity of definitions of VCs, there exists a high diversity of dimensions used to categorize VCs (for an overview, see also Leimeister [11] and Leimeister et al. [12]). Despite the large number of dimensions, researchers have argued that many existing VCs cannot be categorized unambiguously. On one hand, the reason for the difficulty in categorization may be due to the particular specification of the VC. For example, a community for breast cancer patients with a regional focus can be classified as (a) a geographic community because of the regional focus; (b) a demographic community because of the focus on women; and (c) a themecentered community, as the focus is issues related to breast cancer (these categories are taken from Hagel \& Armstrong [10]). Conversely, the difficulties encountered in attempting to categorize VCs might be caused by the fact that the existing categories are overlapping [6]. To keep the field of VCs for a first empirical exploration as broad as possible and to be able to categorize VCs unambiguously, we used the financial interest of the operators of the community as criterion to categorize VCs. Hence, we distinguish commercial and noncommercial communities.

\subsection{Success and Success Factors of VCs}

The success of a VC can be measured from different perspectives according to the different stakeholders of a community. Some authors have distinguished several stakeholders within a VC, especially in terms of its organization. Butler et al. [13], for example, distinguished volunteers, equity holders, and payroll employees as stakeholders each with their own motivation for involvement in the VC.

From the perspective of members of VCs, Blanchard and Markus [14, 15] have identified the "sense of virtual community" among members as a characteristic of a successful VC. With respect to social interactions taking place in successful communities, empirical research has identified some characteristics in more detail such as exchange of support or shared emotional connections among members $[9,16$, 17]; influence of members in terms of enforcing and challenging norms $[7,16,18$, 19]; or indicators of boundaries, belonging, and group symbols [20-23]. From the 
perspective of operators, very often other criteria (also according to the purpose of the community) have been mentioned such as economic aspects and figures (e.g., return on investment $[24,25]$ or the number of generated leads for marketing purposes [26]).

For this article, we focus solely on operators and members of VCs as relevant stakeholders. As the focus of this work was not on a specific type of VC, this distinction was the most common denominator for differentiating stakeholders within communities of different types.

We used financial success (when applicable), lifetime (existence on the market), and continuous growth of membership and growth of user-generated content as indicators to measure the success of a VC.

Research on success factors has generally focused on the search for methods and models that explain how to achieve and maximize success in companies. Studies have attempted to provide recommendations, as detailed as possible, on how to provide and use resources in an ideal way. The recommendations are often insufficient, as the number of influencing variables is high, and correlation between variables is extremely diverse. A better approach is for research to focus on formulating guidelines that can be influenced by the operators and that result in a strategy that is expected to be successful [27]. Such orientation principles do not claim to fully explain all correlations but try to give new ideas for the conception of approaches that might be more effective. To evaluate factors that contribute to the success of VCs, we first summarize success factors of VCs as found in literature (for further reading on the extraction of success factors from literature, see Sidiras [28]) and evaluate them according to their importance for operators (the term operator is used for describing the party that runs and manages a VC) and members of VCs.

Many authors have dedicated themselves to economic aspects of VCs; early strategy papers by Armstrong and Hagel [1,2] and Hagel and Armstrong [10] were published in the mid 1990s. Various (often prescriptive) papers have dealt with the issue of designing VCs [5, 7, 29-33]. Preece [17] and Maloney-Krichmar and Preece [34], for example, have stressed the role of social infrastructure provided by thoughtful user interface design and the importance of balancing emotional and factual communication among community members. Arnold et al. [35] mentioned the importance of an iterative, end-user, involving, and continuous development process of a VC and its underlying platform. Williams and Cothrel [36] stressed the role of a critical mass of functionality at the user's disposition and the need for reaching a critical mass of users within the shortest possible time. Various authors have addressed the issue of trust in VCs [37-40]. As Ginsburg and Weisband [41] mentioned within the context of commercial VCs, trust in VCs is closely related to the issues of trust in Internet-based transactions in electronic commerce in general. Ginsburg and Weisband [41] also stressed (for the domain of gaming communities) the importance of sophisticated interface design, support for volunteerism, and the importance of the transfer of real-life status symbols to the virtual world as well as the important role of planned evolution [42] for the success of a VC. Bughin and Hagel [24] and Bughin and Zeisser [43] have mentioned the importance of supporting the operational performance of VCs to ensure positive business performance and long-term survival. Andrews $[44,45]$ has put emphasis on the thorough understanding of an audience's distinctive demographic, psycho-demographic, and 
Internet experience characteristics as being critical to crafting solutions that increase the ability to build sustainable online communities. Eisentraut et al. [46] addressed the issue of how to support trust building and trust transfer, whereas Lechner and Hummel [47] and Lechner and Schmid [48] have dealt with the economic potential of the business model VC and have stressed that this economic potential lies in the integration of an organized community in various roles and at almost all stages in the value chain and not only in the combination of social needs and transactions as other authors would claim. Despite these different approaches to VCs and to their business-related aspects, many success factors for reaching the postulated potentials remain unclear and unanswered. It is important to note that the "ingredients" of successful VCs have been analyzed only sparsely and have hardly been substantiated empirically. The weights of different identified success factors for the overall success of VCs also remain unclear.

A review of the literature revealed a great diversity of factors that influence the success of VCs. With regard to the evaluation of these factors, in this study, we differentiate between member- and operator-oriented success factors. Given the diversity of concepts regarding VCs that have been presented in the literature, extracted factors had to be heterogeneous and referred to different definitions and understandings of VCs. To overcome this weakness, we conducted a Delphi study among 20 experts on VCs from academia to condense and achieve agreement on the different factors. Each of the experts had themselves conducted research on VCs and had published at least one article at the online community minitracks of the Hawaiian International Conference on System Sciences or Americas Conference on Information Systems prior to April 2002. The Delphi approach is used for prediction and decision support of complex qualitative problems that cannot be extrapolated as a trend from previous data. A group of dispersed experts analyzes and rates success factors of VCs asynchronously, anonymously, and with feedback on the results of the aggregated group results over several iterations [49].

Of 20 identified experts, 13 returned both questionnaires and rankings of success factors for two iterations. The results of this two-level Delphi study [28] conducted among experts in the field of VCs were the basis for reviewing expansion and adjustment of the original set of success factors as found in literature. In the Delphi study, we also tested potential correlations between the success factors. Table 1 gives an overview of the condensed success factors.

Altogether, we identified 32 factors: After confronting respondents with the previous working definition of VCs, we presented 26 factors to members and all 32 to the operators (the 6 factors that are merely operator oriented are highlighted in grey in Table 1). To be able to identify the success factors more easily, we assigned an identification number to each.

\section{RESEARCH METHOD}

We built the design and procedure of the study on the model of designing empirical studies presented by Nieschlag et al. [50], a known and widely accepted model in the German social sciences. The model consists of five stages and has been implemented in numerous studies. We adapted it to this problem by taking into consideration the medium of data collection (see Figure 1). We removed an online survey 
Table 1

Success Factors of Virtual Communities As Found in the Literature and Condensed Through a Delphi Study

Success Factors ${ }^{\mathrm{a}}$

ID No.

Reaching a high number of members within a short period of time 1

$\begin{array}{ll}\text { Building trust among the members } & 2\end{array}$

Evolution of the community according to the ideas of its members 3

Offering up-to-date content $\quad 4$

$\begin{array}{ll}\text { Offering high-quality content } & 5\end{array}$

Appreciation of contributions of members by the operator $\quad 6$

$\begin{array}{ll}\text { Assistance for new members by experienced members } & 7\end{array}$

Establishing codes of behavior (netiquette/guidelines) to contain conflict potential 8

Supporting the community by regular real-world ${ }^{b}$ meetings $\quad 9$

$\begin{array}{lr}\text { Handling member data sensitively } & 10\end{array}$

$\begin{array}{ll}\text { Arranging regular events } & 11\end{array}$

$\begin{array}{ll}\text { Intuitive user guidance } & 12\end{array}$

Personalized page design of the community site according to the preferences of its members 13

$\begin{array}{ll}\text { Establishing and supporting subgroups within the community } & 14\end{array}$

Integration of the members into the administration of the community $\quad 15$

$\begin{array}{ll}\text { Fast reaction time of the Website } & 16\end{array}$

$\begin{array}{ll}\text { Stability of the Website } & 17\end{array}$

$\begin{array}{ll}\text { Price efficiency of offered products and services } & 18\end{array}$

$\begin{array}{ll}\text { Encouraging interaction between members } & 19\end{array}$

Offering privileges or bonus programs to members $\quad 20$

$\begin{array}{ll}\text { Special treatment of loyal members } & 21\end{array}$

$\begin{array}{lr}\text { Personalized product and service offers for members } & 22\end{array}$

$\begin{array}{ll}\text { Focusing on one target group } & 23\end{array}$

Continuous community controlling with regard to the frequency of visits 24

Continuous community controlling with regard to member growth 25

Continuous community controlling with regard to member satisfaction 26

Defining sources of revenue as a starting condition for building a virtual community 27

$\begin{array}{ll}\text { Constant extension of offerings } & 28\end{array}$

$\begin{array}{ll}\text { Building a strong trademark } & 29\end{array}$

$\begin{array}{ll}\text { Existence of an offline customer club as a starting advantage } & 30\end{array}$

$\begin{array}{ll}\text { Increase of market transparency for community members } & 31\end{array}$

Sustaining neutrality when presenting and selecting offers to community members 32

Note. Assigned identification numbers and operator-oriented success factors, presented only to the operators for evaluation, are shaded.

a Listed in order of appearance in the questionnaire. ${ }^{\mathrm{b}}$ The term real world is used as synonymous for offline.

and irrelevant intermediate steps referring to data collection and analysis of paperbased surveys.

For the data collection, we used an overview of VCs by Bullinger [51] because it was the most extensive available listing of German-speaking VCs that most closely coincided with the working definition at the time of the investigation. We used the communities listed in this overview as a starting point. We analyzed each VC concerning its success according to the stated criteria. If the identified community was considered successful, we posted a call for participation in an online questionnaire. Similar to the snowball sampling method, we spotted links to other communities. 
We also analyzed the additional communities for success and if they met the criteria, we posted calls for participation on them as well. Altogether, we posted messages in 160 VCs (for a complete listing, see Sidiras [28]), covering a wide variety of online communities in respect to both size and type of community. The communities involved in the study included gaming communities (e.g., Gamestar, an online community of a German-language computer game magazine), PlayersCommunity (www.playersconvention.de), customer communities (e.g., BMW, Audi, Dell, Ebay), lifestyle communities (e.g., metropolis.de, Germany's largest lifestyle community with 1.5 million registered users; uboot.com, funworld.de, etc.), computing/coding communities (e.g., PDA-Forum, scripts.org, phpcoders.de), sports communities (soccer, borussia-forum.de, basketball, schoenen-dunk.de), and "exotic" special interest communities (e.g., community of dog owners (hunde-foreninfo) to name just few.

We conducted the online survey between July 24, 2002, and August 19, 2002. The numbers of persons surveyed can only be estimated from the number of visits to the online survey, approximately 3,500 visits. The sample consisted of 644 members (434 male and 210 female) and 73 operators ( 34 commercial and 39 noncommercial).

We chose an online survey, a special type of written survey, for data collection. The literature has provided several detailed guidelines on how to build online questionnaires. Three basic principles are included in all of these guidelines: simplicity, neutrality, and accuracy. An explanation of the operationalization of these principles is provided by Büning et al. [52].

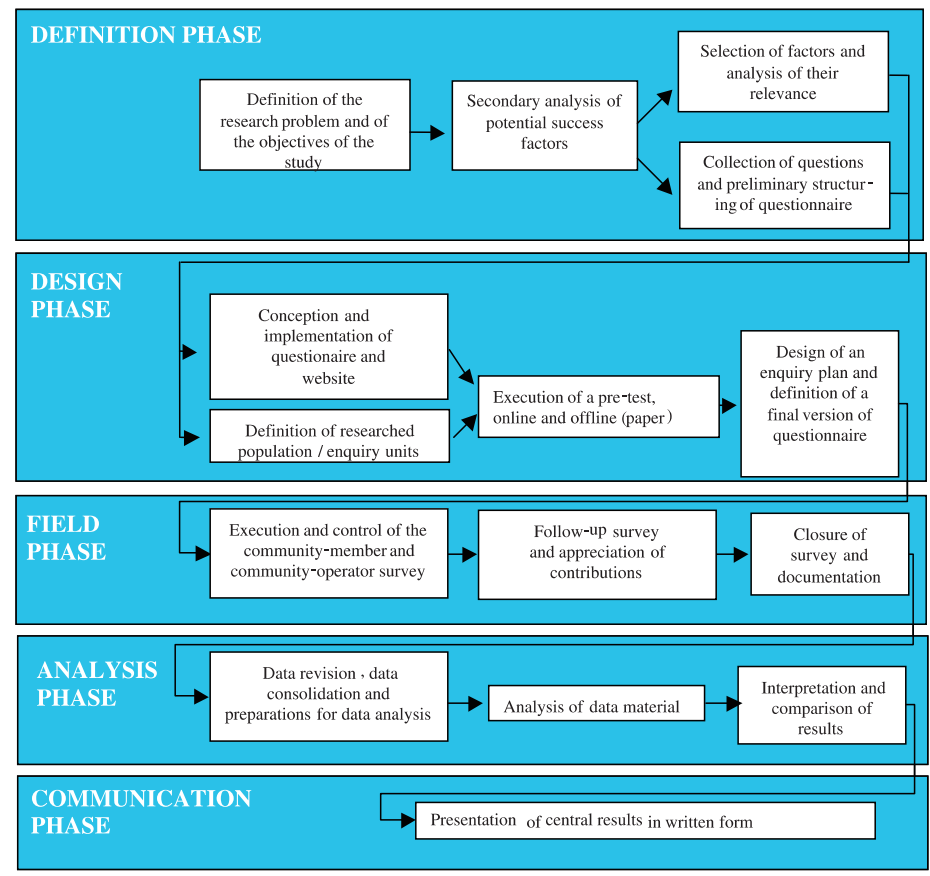

Figure 1. Five stages of the research process. From Marketing (Vol. 19, p. XX) by R. Nieschlag, E. Dichtl, and H. Hörschgen, 2002, Berlin, Germany: Duncker \& Humblot. Copyright (C) 2002 by Duncker \& Humblot. Adapted with permission. 
Online surveys, as a subtype of written surveys, are a special method of collecting data. When posting a questionnaire on the Internet compared to postal mailing or hand-to-hand distribution, it can be stated that only the medium through which the questionnaire is presented has changed. Choosing an online survey as a method to collect data poses some important consequences for the process of the investigation and for the design of the questionnaire. For further details, see Gadeib [53] and Bantinic et al. [54]. In summary, some basic problems occur when conducting an Internet survey: (a) the universe of Internet users is basically undefined [55], and (b) the sample is self-selective and therefore cannot be regarded as being representative; statements about nonparticipants cannot be made [55].

We structured, tested, and consequently adapted the questionnaire we used in this study to the needs of the targeted audience. For this purpose, we administered a pretest to a focus group of six members of VCs followed by a discussion with the test persons. In addition, we did an online pretest with a group of students to test the questionnaire's content and functionality.

The field phase generated a little more than 800 questionnaires for data analysis. After we sorted out incomplete or inconsistent answers, 745 data sets were available for analysis. By dividing the questionnaire into at least two parts and after sorting the responses into groups of interviewees (users and operators, male and female, commercial and noncommercial, etc.), several starting points for comparison became apparent.

We established rankings of success factors (according to the different groups). We tested and compared the differences between arithmetic means. A statistically significant deviation from the means can only be proven by a suited test procedure. In this case, we used a two random-sample test for the difference of two arithmetic means ( $t$ test; cf., e.g., Voß [56]) level of significance (here, $\alpha=.05$ ).

We analyzed questions referring to sociodemographic data as well as to Internet usage and VC usage independently from the analysis of the success factors. The use of a bipolar verbal ordinal scale allowed members to express their agreement or disagreement with the statements (Figure 2). For data analysis, we reinterpreted the descriptive scale into a numerical scale (Figure 2) [57].

We divided data sets into six groups: members (all), members (female), members (male), operators (all), operators (commercial), and operators (noncommercial). In the following section, we compare and contrast these different groups.

\section{ANALYSIS OF THE EMPIRICAL RESULTS}

\subsection{Generic Statements of the Respondents}

Table 2 depicts the responses of the members of the VCs to the question regarding how long on average they stay on the Internet during off and work times. About half of the time online was spent in the respective communities. Of note is that female re-

\begin{tabular}{|c|c|c|c|c|c|}
\hline $\begin{array}{c}\text { Agree strongly } \\
=1\end{array}$ & $\begin{array}{c}\text { Agree } \\
=2\end{array}$ & $\begin{array}{c}\text { undecided } \\
=3\end{array}$ & $\begin{array}{c}\text { reject } \\
=4\end{array}$ & $\begin{array}{c}\text { reject strongly } \\
=5\end{array}$ & $\begin{array}{c}\text { Not specified } \\
=9\end{array}$ \\
\hline
\end{tabular}

Figure 2. Bipolar ordinal scale and reinterpretation into numbers. 
Table 2

Key Data and Answers of the Survey Among Members

\begin{tabular}{|c|c|c|}
\hline Survey Among Members & Male $^{\mathrm{a}}$ & Female $^{\mathrm{b}}$ \\
\hline Period stayed in the internet (hours per day) & 5.01 & 4.6 \\
\hline Period stayed in the community (hours per day) & 2.27 & 2.2 \\
\hline Membership in ... communities & 2.98 & 2.79 \\
\hline Average time of membership (years) & 2.02 & 1.42 \\
\hline Frequency of posting statements in the community ${ }^{c}$ & 2.06 & 2.54 \\
\hline Ordering commercial products via the communityc & 4.62 & 4.63 \\
\hline Satisfaction with the evolution of the communityd & 2.27 & 2.3 \\
\hline Share of members who know other community members in real life (\%) & 52.5 & 65.1 \\
\hline
\end{tabular}

$\mathrm{a}_{n}=434 .{ }^{\mathrm{b}} n=210 .{ }^{\mathrm{c} B a s e d}$ on a scale ranging from 1 (more than once a day) to 5 (never). ${ }^{\mathrm{d} B a s e d}$ on a scale ranging from 1 (very satisfied) to 5 (very unsatisfied).

spondents spent a larger portion of their online period in their communities as compared to male counterparts. On average, respondents were members of three different communities; we did not observe a concentration in only one community. The frequency of both writing and answering messages in the discussion forum was higher for men than for women and correlated positively with the social capital they reported having received in their VC. Seldom did either group order products or services via their VCs. A reason often cited for this has been members' dissatisfaction with the evolution of their community. This assumption, however, was refuted by the survey: Both men and women indicated satisfaction with the evolution of their community.

On average, female respondents reported being members of a community for 1.42 years and men for 2.02 years. However, female respondents reported more intensive personal (unmediated) contacts than male respondents. As compared to $52.5 \%$ of the men, $65.1 \%$ of the women acknowledged they had personally met at least one other member. Although there are no comparable values, both values seem to be relatively high and show that on average, every second respondent, irrespective of sex, knew at least one other community member personally. When interpreting this result, we could conclude that VCs play an important role in establishing personal relationships.

The group of operators (addressees are persons who operate a community, not institutions or companies) can be subdivided into the group of operators with commercial interests and the group of operators with no commercial interests. The survey of operators produced the following results (Table 3). As expected, the length of time the operators were online was much higher than the length of time spent online by members. Interestingly, commercial operators spent less than $50 \%$ of their daily online time in their own communities; on average, operators managed 1.82 communities. Noncommercial operators ran 1.26 communities on average. As to operators' evaluation of their potential profits/potential revenues, an average score of 2.9, which corresponds with the answer category "uncertain," was given by both commercial and noncommercial operators.

As to reported satisfaction with the evolution of their community, on average, both commercial and noncommercial operators indicated that they were "satis- 
Table 3

Key Data and Answers of the Survey Among Operators

\begin{tabular}{lcc}
\hline Survey Among Operators & Commercial $^{\mathrm{a}}$ & Noncommercial $^{\mathrm{b}}$ \\
\hline Period stayed in the internet (hours per day) & 7.28 & 6.13 \\
Period stayed in the community (hours per day) & 3.46 & 2.68 \\
Operators of ... communities & 1.82 & 1.26 \\
Average time of operation (years) & 1.86 & 1.32 \\
Frequency of making statements in the communityc & 2.09 & 1.72 \\
Evaluation of the potential to make profit in the community ${ }^{\mathrm{d}}$ & 2.84 & 2.97 \\
Satisfaction with the evolution of the communitye & 2.03 & 2.15 \\
Share of operators who know members in real life (\%) & 73.5 & 76.3 \\
\hline
\end{tabular}

${ }^{a} n=34 .{ }^{b} n=39 .{ }^{c}$ Based on a scale ranging from 1 (more than once a day) to 5 (never). ${ }^{\mathrm{d} B a s e d}$ on a scale

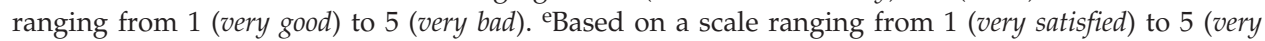
unsatisfied).

fied" with the evolution of their community (2.03 for commercial and 2.15 for noncommercial operators). The reported reasons for satisfaction with evolution included the growing number of members and the interaction between members. The percent of commercial $(73.5 \%)$ and noncommercial $(76.3 \%)$ operators who reported personally knowing members seems relatively high. An explanation for this might be that operators get to know members in real life when trying to organize community meetings.

\subsection{Analysis of the Success Factors From the Perspective of Female and Male Members of VCs}

Table 4 shows the ranking of the importance of individual success factors as they were perceived by all members. In addition, Table 4 depicts how success factors were ranked by male and female community members separately. In the last column of Table 4, deviations between males and females are presented.

The ranking shows that in the perception of the members, the "handling member data sensitively" was the most important factor contributing to the success of a VC. This was followed by more technical success factors such as stability and reaction time of the Web site. Further more content-related factors were also ranked high, which emphasizes the role of high-quality and up-to-date content.

Of interest was the analysis of success factors as ranked by men and women. Significant deviations (level of significance $\alpha>$.05) between men and women and therefore different evaluations of the importance of specific success factors were measured in eight cases (Table 4, deviations highlighted in grey in the last column).

The success factor "supporting the community by regular real-world meetings" was evaluated as medium important by both men and women, although women $(M=2.69)$ rated it of slightly more importance than men $(M=2.91)$. This same situation exists, for example, in traditional self-help groups in which female participants generally outnumber male participants. In contrast, the success factor "encouraging interaction between members" was evaluated to be more important to men than to women $(M=1.99$ compared to $M=2.6$, respectively). Therefore, although real-world contact between community members is less important to men 
Table 4

Overall Ranking and Means of the Success Factors by Members and Breakdown of the Results to Males and Females

\begin{tabular}{|c|c|c|c|c|c|c|c|}
\hline \multicolumn{2}{|c|}{ Overall Success Factors Ranking } & \multirow{2}{*}{$\begin{array}{c}\begin{array}{c}\text { Overall } \\
M\end{array} \\
1.344\end{array}$} & \multirow{2}{*}{$\begin{array}{c}\begin{array}{c}M \\
\text { Females }\end{array} \\
1.257\end{array}$} & \multirow{2}{*}{$\begin{array}{c}\begin{array}{c}\text { Ranking } \\
\text { Female }\end{array} \\
1\end{array}$} & \multirow{2}{*}{$\begin{array}{c}\text { M } \\
\text { Male } \\
1.385\end{array}$} & \multirow{2}{*}{$\begin{array}{c}\begin{array}{c}\text { Ranking } \\
\text { Males }\end{array} \\
1\end{array}$} & \multirow{2}{*}{$\begin{array}{c}\begin{array}{c}\text { Deviation } \\
\text { Males Versus } \\
\text { Females }\end{array} \\
.1279\end{array}$} \\
\hline 1 & $\begin{array}{l}\text { Handling member data } \\
\text { sensitively }\end{array}$ & & & & & & \\
\hline 2 & Stability of the Website & 1.450 & 1.461 & 2 & 1.444 & 2 & .0170 \\
\hline 3 & $\begin{array}{l}\text { Fast reaction time of the } \\
\text { Website }\end{array}$ & 1.592 & 1.485 & 3 & 1.640 & 3 & .1549 \\
\hline 4 & $\begin{array}{l}\text { Assistance for new } \\
\text { members by experienced } \\
\text { members }\end{array}$ & 1.777 & 1.758 & 5 & 1.786 & 4 & .0276 \\
\hline 5 & $\begin{array}{l}\text { Establishing codes of } \\
\text { behavior (netiquette/ } \\
\text { guidelines) to contain } \\
\text { conflict potential }\end{array}$ & 1.781 & 1.738 & 4 & 1.802 & 5 & .0645 \\
\hline 6 & Offering up-to-date content & 1.898 & 1.874 & 6 & 1.910 & 7 & .0366 \\
\hline 7 & $\begin{array}{l}\text { Offering high-quality } \\
\text { content }\end{array}$ & 1.907 & 1.990 & 7 & 1.867 & 6 & .1236 \\
\hline 8 & $\begin{array}{l}\text { Encouraging interaction } \\
\text { between members }\end{array}$ & 2.047 & 2.163 & 10 & 1.990 & 8 & .1731 \\
\hline 9 & $\begin{array}{l}\text { Evolution of the community } \\
\text { according to the ideas of its } \\
\text { members }\end{array}$ & 2.068 & 2.020 & 8 & 2.090 & 9 & .0701 \\
\hline 10 & $\begin{array}{l}\text { Building trust among the } \\
\text { members }\end{array}$ & 2.092 & 2.039 & 9 & 2.118 & 10 & .0788 \\
\hline 11 & $\begin{array}{l}\text { Sustaining neutrality when } \\
\text { presenting and selecting } \\
\text { offers }\end{array}$ & 2.250 & 2.259 & 11 & 2.246 & 12 & .0130 \\
\hline 12 & $\begin{array}{l}\text { Intuitive user guidance/ } \\
\text { usability }\end{array}$ & 2.255 & 2.311 & 12 & 2.229 & 11 & .0819 \\
\hline 13 & $\begin{array}{l}\text { Constant extension of } \\
\text { offerings }\end{array}$ & 2.440 & 2.487 & 13 & 2.418 & 13 & .0688 \\
\hline 14 & $\begin{array}{l}\text { Price efficiency of offered } \\
\text { products and services }\end{array}$ & 2.539 & 2.558 & 14 & 2.529 & 14 & .0287 \\
\hline 15 & $\begin{array}{l}\text { Reaching a high number of } \\
\text { members within a short } \\
\text { period of time }\end{array}$ & 2.738 & 2.827 & 20 & 2.696 & 15 & .1303 \\
\hline 16 & $\begin{array}{l}\text { Personalized page design of } \\
\text { the community site } \\
\text { according to the preferences } \\
\text { of its members }\end{array}$ & 2.781 & 2.675 & 16 & 2.833 & 19 & .1578 \\
\hline 17 & $\begin{array}{l}\text { Integration of the members } \\
\text { into the administration of } \\
\text { the community }\end{array}$ & 2.790 & 2.942 & 22 & 2.718 & 16 & .2239 \\
\hline 18 & Arranging regular events & 2.796 & 2.767 & 19 & 2.810 & 18 & .0431 \\
\hline 19 & $\begin{array}{l}\text { Increase of market } \\
\text { transparency for } \\
\text { community members }\end{array}$ & 2.806 & 2.661 & 15 & 2.878 & 20 & .2171 \\
\hline 20 & $\begin{array}{l}\text { Appreciation of } \\
\text { contributions of the } \\
\text { members by the operators }\end{array}$ & 2.830 & 2.878 & 21 & 2.807 & 17 & .0704 \\
\hline
\end{tabular}


Table 4 Continued

\begin{tabular}{llccccc}
\hline Overall Success Factors Ranking & $\begin{array}{c}M \\
M\end{array}$ & $\begin{array}{c}\text { Ranking } \\
\text { Females }\end{array}$ & $\begin{array}{c}M \\
\text { Fale }\end{array}$ & $\begin{array}{c}\text { Ranking } \\
\text { Males }\end{array}$ & $\begin{array}{c}\text { Males Versus } \\
\text { Females }\end{array}$ \\
\hline $21 \quad \begin{array}{l}\text { Supporting the community } \\
\text { by regular real-world } \\
\text { meetings }\end{array}$ & 2.839 & 2.691 & 17 & 2.911 & 21 & .2203 \\
$22 \begin{array}{l}\text { Offering privileges or } \\
\text { bonus programs to } \\
\text { members }\end{array}$ & 2.877 & 2.743 & 18 & 2.938 & 22 & .1885 \\
23 Establishing and \\
$\begin{array}{l}\text { supporting subgroups } \\
\text { within the community }\end{array}$
\end{tabular}

Note. Significant deviations between male and female members are shaded.

than to women, men in this study seemed to take virtual interaction more seriously than their female counterparts. This result supports the assumption that women have a higher inhibition threshold with regard to communication within the community than men; this was supported by the finding that women posted less messages within the community than did men (see 4.1.), whereas men attached less importance to the real-world advancement of the relationships established in the community than did women (Table 4, section 4.1).

These results could indicate that women might possibly use the community to make new contacts that could be intensified in the real world. Men, on the other hand, focus on the process of making new contacts but not necessarily intensifying them.

The highest deviation between male and female community members was observed in the comparison of the ratings of the success factor "existence of an offline customer club as a starting advantage." Female community members ranked this success factor of significantly more importance than did male members. Although this factor was ranked lowest by both groups, the higher rating the women gave supports the previously discussed assumption that women desire offline contact with other members.

Regarding the success factor "integration of the members into the administration of the community" (involvement in tasks that only affect the VC and its administration), the picture changed again. Men clearly evaluated the importance of participation in administrative tasks (and similar tasks such as facilitating a forum) higher than women ( $M=2.72$ compared to $M=2.94$, respectively).

Summarizing the previous paragraphs, it is noticeable that success factors regarding offline communication and offline interaction were evaluated to be more impor- 
tant to female respondents than to male respondents. Success factors relating to interaction within the community, such as posting contributions and performing a task within the community, were rated as being more important to male respondents than to female respondents. This insight was supported by answers to the overall questions such as the share of personal contacts that evolved from the community or the frequency of posting messages (see 4.1). It was also supported by the analysis of answers to open questions asking for explanations for user satisfaction with the communities and for personal contacts emerging from the community.

Male and female members differ significantly in their evaluation of the success factor "personalized page design of community site," although we should state that this difference was relatively small and just exceeded the threshold level of the testing procedure $(M=2.83$ for male respondents compared to $M=2.68$ for female respondents, which accounts for a rank of 19 for men and 16 for women). As both calculated means could be interpreted as "undecided" scores, we could also assume that the operators had not been successful in their efforts to create a sense of identity or belonging through customizing page designs to meet the interests of members.

There was greater agreement between the rankings of men and women with regard to more technically oriented success factors. However, in response to the success factor "fast reaction time of the Web site," male respondents reported more patience with regard to long waiting times than did women $(M=1.64$ compared to $M=1.48$, respectively). Men ranked this success factor third exceeded only by "stability of the Web site" and "handling member data sensitively." Women seemed to be more demanding in terms of datedness and quality of published material. Although the ranking given to these factors by male respondents differed only slightly from the ranking by female respondents, the absolute values as evaluated by men were clearly less than those of female respondents. We note a similar difference in the reported level of importance in the rating of the success factor "handling member data sensitively." In terms of absolute values, women rated the use of personal data as more important than did men $(M=1.26$ compared to $M=1.39$, respectively). Overall, the sensitive handling of personal data was ranked as most important by both male and female respondents.

\subsection{Analysis of the Success Factors From the Perspective of Operators of VCs and Comparison Between Statements Made by Operators of Commercial and Noncommercial VCs}

In the analysis we conducted, no significant differences in responses between operators of commercial and noncommercial communities were demonstrated. Despite the missing preconditions for the analysis of the success factors, the results are presented in Table 5, as some of the means are very close to the threshold level of the testing procedure.

The differences between the success factors with ID 20 and 25 are clearly apparent. Testing the differences on their significance, the threshold level was narrow. However, the differences are clear enough that no statements valid at this significance level could be formulated. 


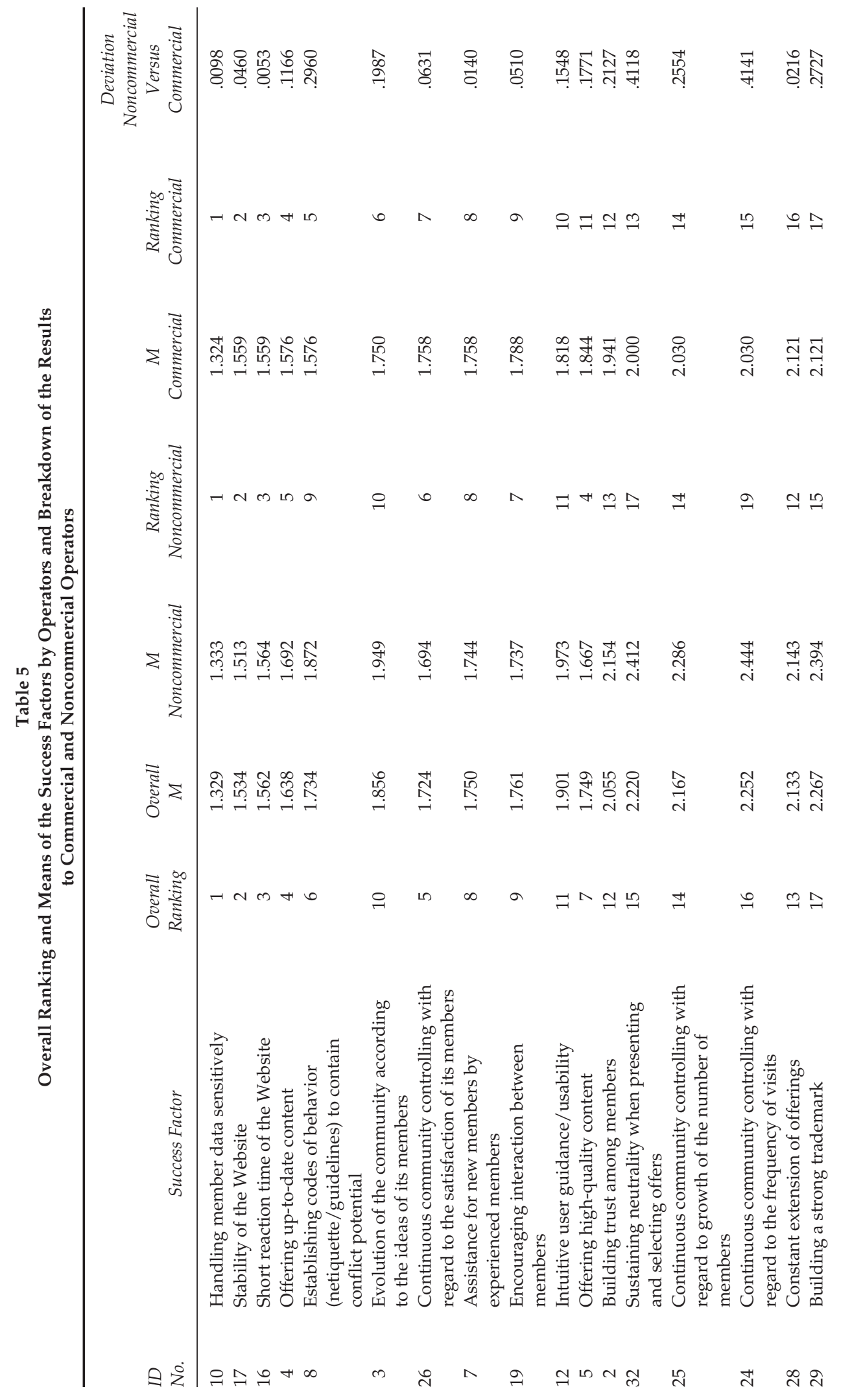




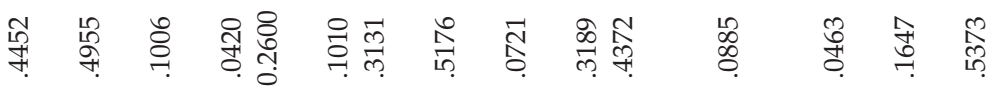

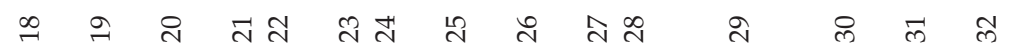

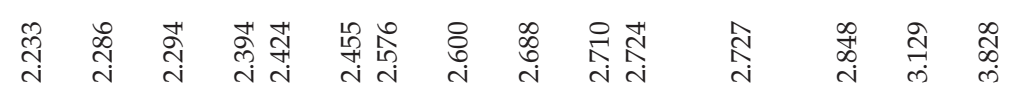

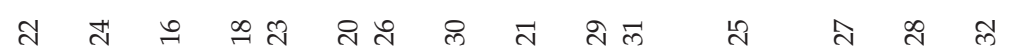

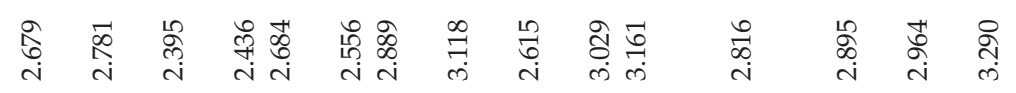

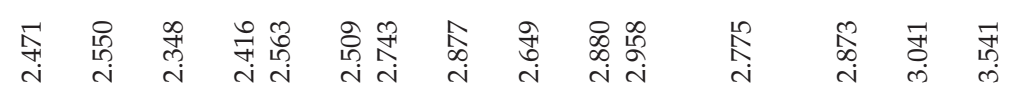

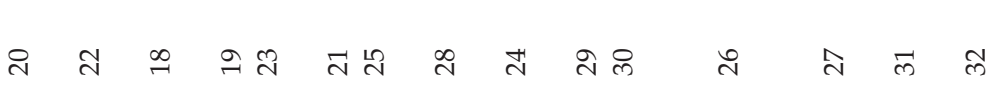

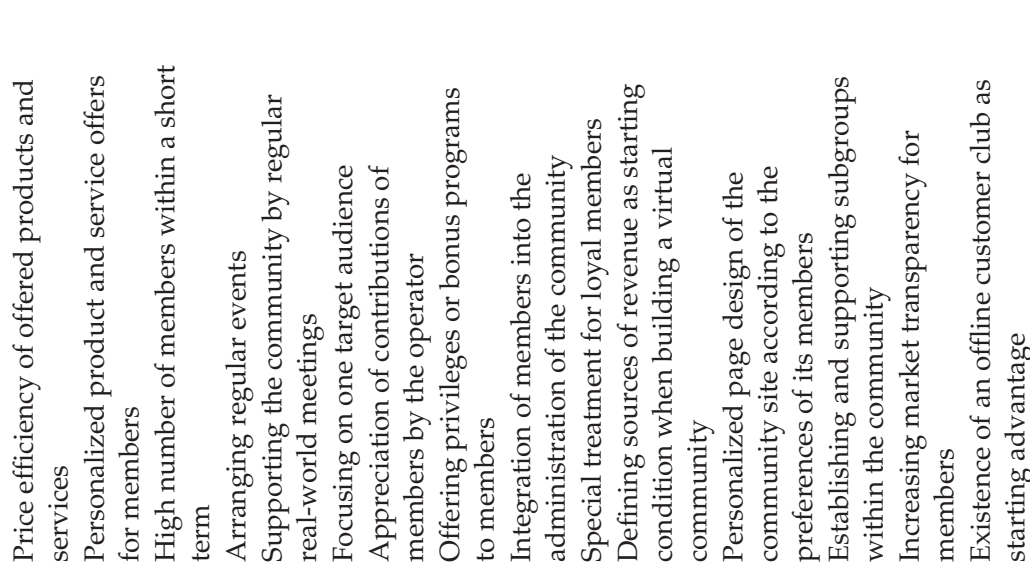


Therefore, the expected confrontation between commercially and noncommercially oriented communities was not demonstrated by the study results, at least not by the operator respondent groups. Although disagreement between the operators was not apparent, the study results demonstrate a wide range of disagreement between the commercially oriented operators and the members as a whole.

\subsection{Comparison Between the Operators and the Members of VCs}

\subsubsection{Comparison Between Noncommercial Operators of VCs and Members.}

Presuming that operators without commercial motivation deal with their community because of an intrinsic motivation, few differences between members of VCs and noncommercial operators were expected (Figure 3).

Supporting this assumption, only two success factors of significant difference could be identified:

- ID 11: Arranging regular events.

- ID 19: Encouraging interaction between members.

Taking into account that the success factor evaluated as least important by members accounts for a mean of 3.5, the average importance mean of 2.8 for "arranging regular events" seems to be relatively deflating. This result is even more surprising because the literature has described events as refreshing for community life and attractive to members [10]. Operators on average evaluated the importance of this success factor higher than members $(M=2.44)$. Nevertheless, the relatively low interest of community members of both genders in events remains surprising. Another unexpected result was the evaluation of the clearly community-oriented success factor "encouraging interaction between members," which was evaluated higher than the previously mentioned success factor $(M=2.05$ for members and $M=$ 1.74 for operators). Overall, the "population" of the community put less emphasis on encouraging interaction from the outside than operators.

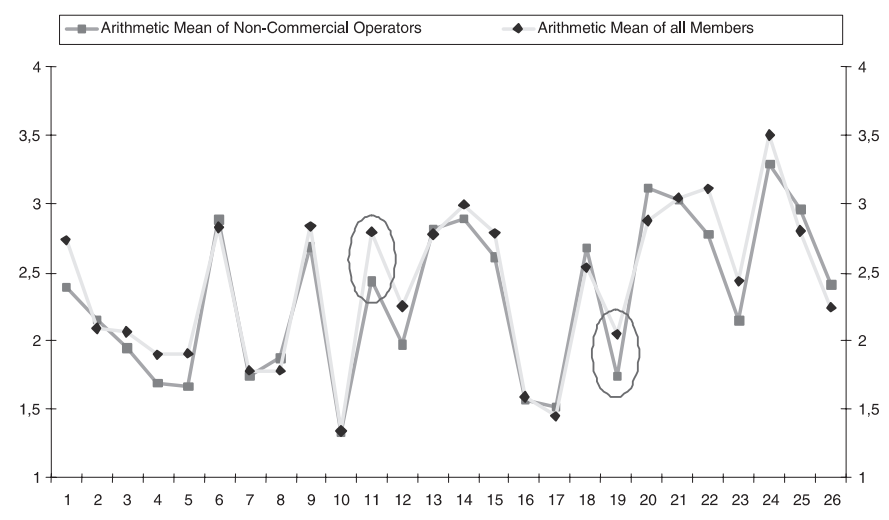

Figure 3. Evaluation of success factors by noncommercial operators and members. 
The small number of differences between noncommercial operators and members demonstrated, to a large extent, that noncommercial operators and members were in agreement on factors that contribute to the success of VCs.

\subsubsection{Comparison Between the Statements of Commercial Operators of VCs} and Members. Operators of commercially oriented communities are strongly dependent on the satisfaction and buying practices of current and potential members for their success. In this light, the high number of significant deviations between members and commercial operators was especially surprising (to better visualize this result, a frequency polygon was chosen; see Figure 4). In the sample, operators and members identified somewhat different criteria as being important for the community. We discuss the following success factors in more detail:

- ID 1: Reaching a high number of members in a shorter period of time.

- ID 3: Evolution of the community according to the ideas of the members.

- ID 4: Offering of up-to-date content.

- ID 9: Supporting the community by regular real-world meetings.

- ID 11: Arranging regular events.

- ID 12: Intuitive user guidance/usability.

- ID 22: Personalized product and service offers for members.

Although the success factor "reaching a high number of members within a short period of time" was ranked number 20 by commercial operators, an average importance mean of 2.29 was reported as compared to an average importance of 2.74 for members, which coincides with rank 15 in their ranking list (we take into account that 32 success factors were presented to the operators, whereas only 26 were presented to the members). This result supports the assumption that reaching a large number of members within a short period of time is important to operators because of their dependency on day-to-day business. Even if not as much revenue is generated as may have been anticipated during the initial phases of a community, frequent visitors and a growing number of members are good predictors of future growth in revenue. In contrast, the members responding to this survey

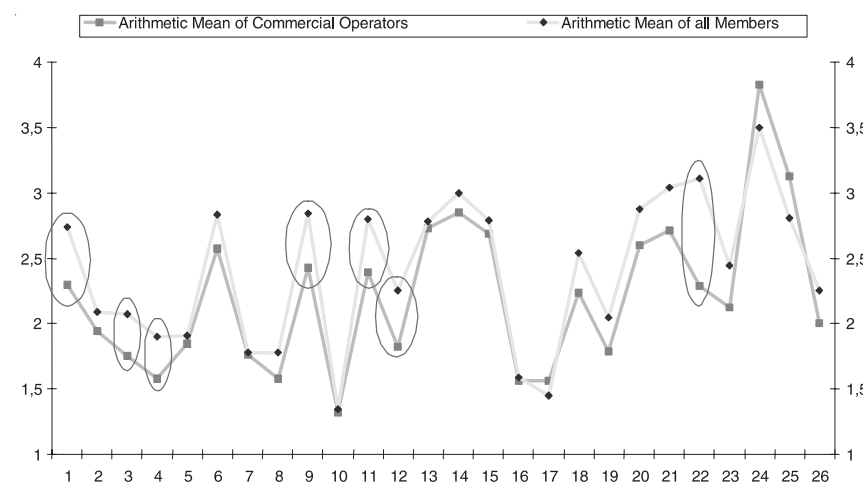

Figure 4. Evaluation of success factors by commercial operators and members. 
seemed to prefer smaller sized communities, or at least they did not see a high number of members as a precondition for their participation in a community. This is an unexpected result taking into account that respondents ranked "establishing and supporting subgroups within the community" on position 23 of 26 possible. If smaller group sizes are indeed preferred, it would be expected that this factor would be ranked higher.

When comparing both graphs in Figure 3, we can state that for each of the relevant deviations, the group of operators evaluated the success factor as more important than the members did.

Most clearly, this phenomenon occurs for the success factors "intuitive user guidance/usability" and "personalized product and service offers for members." In the case of "personalised product and service offers for members," the threshold level of the test statistics was exceeded more than twice $(M=2.29$ for operators compared to $M=3.11$ for members).

In this study, we can neither confirm nor dispute that personalized offers influenced the community members. As "handling member data sensitively" was clearly ranked highest, the result we described for "personalized product and service offers for members" was not surprising. Due to the fact that most of the participating members were active in noncommercial communities, we can postulate that respondents were critical toward commercialization of VCs.

3.4.3 Comparison Between the Statements of All Operators and Members. After the detailed comparisons in the two previous sections, an additional comparison might seem to be unnecessary. However, because of the increased sample size (taking all operators into consideration) and the slightly changed variance of the statements, the testing procedure reveals one additional deviation:

- ID 23: Constant extension of offerings.

The "constant extension of offerings" was evaluated to be more important to community operators $(M=2.12)$ than to community members $(M=2.44)$. Operators consider the extension of their offerings as a natural evolution. By extending their offerings, they distinguish themselves from other communities and attempt to open up new markets. Members did not consider this success factor as unattractive. However, this factor did not mean as much to them as, for example, "sustaining neutrality when presenting and selecting offers" $(M=2.25)$.

\section{CONCLUSIONS AND OUTLOOK}

The following recommendations for building and managing VCs can be derived from the collected and analyzed data and the previously described results:

- Performance and security matter: The design of a technically performant platform with high stability and technical security is one of the most important success factors for a VC.

- Content is king: A limitation to communication/interaction services is only promising for a short period of time. When aiming at sustainable success of a com- 
munity, in addition to user-generated content, high-quality and up-to-date information should be provided.

- Member data are sensitive resources: Handling member data/profiles sensitively is a vital success factor. Therefore, selling user data to third parties could be counterproductive.

- Do not be technology or feature driven: The inclusion of innovative features such as automated personalized offerings rarely fulfills promises per se. Community builders should rather focus on performance and reliability of the platform.

- Manage community discretely and expediently: Community managers should both be able to react quickly to eventual problems and intervene in community life as little as possible.

- Less is more: Although real-life events are important elements to increase interactivity in VCs, they are evaluated as of lesser importance to community members than to operators. Therefore, the number of events should be limited.

- Let the members participate: Before changing layout or functionalities of a community site, it is important to first give members the opportunity to take part in the modification of design, functionality, and the scope of offerings.

- Provide possibilities for building up social capital and status symbols: Male community members are motivated to take part in a VC by the possibility to easily make new contacts without commitment; they have little intention to transfer these contacts into real life. New contacts are made to satisfy information needs. Building up social capital is more important to male community members than to female members. Examples to support these behaviors include the provision of status symbols or titles for active members or contests such as "member of the month."

- Support member contact and interaction: Female community members are often motivated to take part in a VC to carry on existing contacts without limits of time and place or to extend new online contacts into real life. They are more interested in social interaction and less interested in building up social capital (e.g., by performing tasks in the community or by frequently posting messages). Possibilities for supporting these behaviors are the provision of contact/partner matching services or member profile pages.

Most important, this study revealed that both operators and members clearly focused on performance, security, up-to-dateness, and quality of the content of VCs. The respondents were not focused on the existence of subgroups, special treatments, privileges, or regular meetings but rather on the performance of the Internet presence from both a technical and a content point of view. The success factor ranked to be the most important by all respondents was "handling member data sensitively." This result highlights the significance of data security (even for noncommercial communities) and the need for managers and operators of VCs to be attentive to this issue to foster the success of their site.

In summary, as in this study, we followed an explorative research design, the results should be researched in more detail. Despite the restrictions of this study (e.g., the missing representativeness of the sample and the methodological restrictions of an online survey), the recommendations derived from this study should be verified in a larger study using more detailed and sophisticated empirical instruments. A follow-up study should analyze findings in more detail by using a more in-depth 
categorization of VCs or by defining member subgroups in more detail. Further research should focus on a more varied population of stakeholders of VCs such as volunteers, equity holders, and payroll employees because each group has motivations that could differ from those of the aggregated levels of members and operators. In addition, future studies should evaluate which success factors are most appropriate for which type of VC.

\section{ACKNOWLEDGMENT}

At the time of this research, Jan Marco Leimeister and Pascal Sidiras were affiliated with the Information Systems Department, Hohenheim University.

\section{REFERENCES}

[1] A. Armstrong and J. Hagel III, "Real profits from virtual communities," The McKinsey Quarterly, vol. X, no. X, pp. 128-141, 1995.

[2] A. Armstrong and J. Hagel III, "The real value of online communities," Harvard Business Review, pp. 134-141, MONTH 1996.

[3] H.-J. Bullinger, T. Baumann, N. Fröschle, O. Mack, and T. Trunzer, Business Communities. Bonn, Germany: Galileo, 2002.

[4] J. Preece, Online Communities: Designing Usability, Supporting Sociability. New York: Wiley, 2000.

[5] A. J. Kim, Secret Strategies for Successful Online Communities/Community-Building on the Web. Berkeley. CA: Peachpit, 1999.

[6] J. Brunold, H. Merz, and J. Wagner, Virtual Communities: Strategie, Umsetzung, Erfolgsfaktoren. Landsberg/Lech, Germany: mi, Verlag Moderne Industrie, 2000.

[7] P. Kollock and M. A. Smith, "Managing the virtual commons: Cooperation and conflict in computer communities," in Computer Mediated Communication: Lingusitic, Social and Cross-cultural Perspectives, S. C. Herring, Ed. Amsterdam: Benjamins, 1996.

[8] T. Schoberth and G. Schrott, "Virtual communities," Wirtschaftsinformatik, vol. 43, no. X, pp. 517$519,2001$.

[9] H. Rheingold, The Virtual Community: Homesteading on the Electronic Frontier. Reading, MA: Addison-Wesley, 1993.

[10] J. Hagel III and A. Armstrong, Net Gain: Expanding Markets Through Virtual Communities. Boston: Harvard Business School Press, 1997.

[11] J. M. Leimeister, "Pilotierung virtueller Gemeinschaften im Gesundheitsbereich - bedarfsgerechte Entwicklung, Einführung und Betrieb" ["ENGLISH TRANSLATION”], Information Systems Department, Universität Hohenheim, Stuttgart, unpublished doctoral dissertation, 2004.

[12] J. M. Leimeister, P. Sidiras, and H. Krcmar, "Erfolgsfaktoren virtueller Gemeinschaften aus Sicht von Mitgliedern und Betreibern: Eine empirische Untersuchung" ["ENGLISHTRANSLATION"], presented at 6th Internationale Tagung Wirtschaftsinformatik 2003, Medien - Märkte - Mobilität, Dresden, Germany, 2003.

[13] B. Butler, L. Sproull, S. Kiesler, and R. Kraut, "Community effort in online groups: Who does the work and why?," in Leadership at a Distance, S. Weisband and L. Atwater, Eds. Mahwah, NJ: Lawrence Erlbaum Associates, Inc., 2003.

[14] A. L. Blanchard and M. L. Markus, "The experienced 'sense' of a virtual community: Characteristics and processes," The Data Base for Advances in Information Systems, vol. 35, no. X, pp. 65-79, 2004.

[15] A. L. Blanchard and M. L. Markus, "Sense of virtual community-Maintaining the sense of belonging," presented at 35th HICSS 36, Big Island, Hawaii, 2002.

[16] N. Baym, "The emerge of on-line community," in Cyber Society 2.0: Revisiting Computer-Mediated Communication and Community, S. G. Jones, Ed. Thousand Oaks, CA: Sage, 1998, pp. 35-68. 
[17] J. Preece, "Emphatic communities: Balancing emotional and factual communication," Interacting With Computers, vol. 12, no. X, pp. 63-77, 1999.

[18] N. Pliskin and C. T. Romm, "The impact of e-mail on the evolution of a virtual community during a strike," Information \& Management, vol. 32, no. X, pp. 245-254, 1997.

[19] M. L. McLaughlin, K. K. Osborne, and C. B. Smith, "Standards of conduct on usenet," in Cybersociety: Computer Mediated Communication and Community, S. Jones, Ed. Thousand Oaks, CA: Sage, 1995, pp. XX-XX.

[20] N. Baym, "The emerge of community in computer mediated communication," in CyberSociety: Computer-Mediated Community and Communication, S. G. Jones, Ed. Thousand Oaks, CA: Sage, 1995, pp. 138-163.

[21] P. Curtis, "Mudding: Social phenomenon in text-based virtual realities," in Culture of the Internet, S. Kiesler, Ed. Mahwah, NJ: Lawrence Earlbaum Associates, Inc., 1997, pp. XX-XX.

[22] M. L. Markus, B. Manville, and C. Agres, "What makes a virtual organization work: Lessons from the open source world," Sloan Management Review, vol. 42, no. X, pp. 13-26, 2000.

[23] D. J. Phillips, "Defending the boundaries: Identifying and countering threats in a usenet newsgroup," The Information Society, vol. 12, no. X, pp. 39-62, 1996.

[24] J. Bughin and J. Hagel III, "The operational performance of virtual communities: Towards a successful business model?," Electronic Markets, vol. 10, no. X, pp. 237-243, 2000.

[25] J. Cothrel, "Measuring the success of an online community," Strategy \& Leadership, vol. 28, no. X, pp. 17-21, 2000.

[26] J. Bughin and M. Zeisser, "The marketing scale effectiveness of virtual communities," Electronic Markets, vol. 11, no. X, pp. 258-262, 2001.

[27] V. Tromsdorf, Erfolgsfaktorenforschung, Produktinnovation und Schnittstelle Marketing-FEE [ENGLISH TRANSLATION]. Berlin, Germany: Technische Universität Berlin, 1990.

[28] P. Sidiras, "Erfolgsfaktoren virtueller Gemeinschaften: Eine Analyse und Gegenüberstellung empirischer Untersuchungen," Information Systems Department, Stuttgart-Hohenheim, Hohenheim University, unpublished master's thesis 2002.

[29] C. Figallo, Hosting Web Communities: Building Relationships, Increasing Customer Loyalty and Maintaining a Competitive Edge. New York: Wiley, 1998.

[30] P. Kollock and M. A. Smith, "Communities in cyberspace," in Communities in Cyberspace, M. A. Smith and P. Kollock, Eds. London: Routledge, 1999, pp. 3-25.

[31] E. D. Mynatt, A. Adler, M. Ito, and V. O'Day, "Design for network communities," presented at CHI 97, CITY, STATE, 1997.

[32] R. Benjamin, "Cybercommunities: Better than being there?," in Blueprint to the Digital Economy: Creating Wealth in the Era of E-Business, D. Tapscott, A. Lowy, and D. Ticoll, Eds. New York: McGraw-Hill, 1998, pp. 299-316.

[33] J. Cothrel and R. L. Williams, "On-line communities: Helping them form and grow," Journal of Knowledge Management, vol. 3, no. X, pp. 54-60, 1999.

[34] D. Maloney-Krichmar and J. Preece, "Online communities: Focusing on sociability and usability," in The Human-Computer Interaction Handbook: Fundamental, Evolving Technologies, and Emerging Applications. Mahwah, NJ: Lawrence Erlbaum Associates, Inc., 2003, pp. 596-620.

[35] Y. Arnold, J. M. Leimeister, and H. Krcmar, "COPEP: A development process model for a community platform for cancer patients," presented at 11th European Conf. Information Systems (ECIS), Naples, Italy, 2003.

[36] R. Williams and J. Cothrel, "Four smart ways to run online communities," Sloan Management Review, vol. 41, no. X, pp. 81-91, 2000.

[37] A. Abdul-Rahman and S. Hailes, "Supporting trust in virtual communities," presented at HICSS 33, 2000, Maui, Hawaii, 2000.

[38] W. Ebner, J. M. Leimeister, and H. Krcmar, "Trust in virtual health care communities: Design and implementation of trust-enabling functionalities," presented at HICSS 37, Big Island, Hawaii, 2004.

[39] C. Figallo, “Tools, techniques \& trust. What makes a good virtual community?: Human and social perspectives," presented at 1st Int. Conf. on Virtual Communities, Bath, England, 1998.

[40] C. Ridings, D. Gefen, and B. Arinze, "Some antecedents and effects of trust in virtual communities," Journal of Strategic Information Systems, vol. 11, no. X, pp. 271-295, 2002. 


\section{LEIMEISTER, SIDIRAS, KRCMAR}

[41] M. Ginsburg and S. Weisband, "A framework for virtual community business success: The case of the internet chess club," presented at HICSS 37, Big Island, Hawaii, 2004.

[42] M. Ginsburg, "Growing out of its skin: Principles of the evolution and extension of the internet chess club, 1995 to present," presented at AMCIS, Boston, 2001.

[43] J. Bughin and M. Zeisser, "The marketing scale effectiveness of virtual communities," presented at AMCIS 2001, Boston, 2001.

[44] D. Andrews, "Considerations in the development of commercially based online communities," presented at AMCIS 2001, Boston, 2001.

[45] D. Andrews, "Audience-specific online community design," Comm. of the ACM, vol. 45, no. X, pp. 64-68, 2002.

[46] R. Eisentraut, M. Koch, and K. Möslein, "Building trust and reputation in communities and virtual enterprises," presented at AMCIS 2001, Boston, 2001.

[47] U. Lechner and J. Hummel, "Business models and system architectures of virtual communities: From a sociological phenomenon to peer-to-peer architectures," International Journal of Electronic Commerce, vol. 6, no. X, pp. 41-53, 2002.

[48] U. Lechner and B. F. Schmid, "Communities: Business models and system architectures: The blueprint of mp3.com, Napster and Gnutella revisited," presented at HICSS XX, ISLAND, Hawaii, 2001.

[49] G. Rowe and G. Wright, "The Delphi technique as a forecasting tool: issues and analysis," International Journal of Forecasting, vol. 15, no. X, pp. 353-375, 1999.

[50] R. Nieschlag, E. Dichtl, and H. Hörschgen, Marketing, überarbeitete und ergänzte Auflage ed., vol. 19. Berlin, Germany: Duncker \& Humblot, 2002.

[51] H. Bullinger, Business Communities als integraler Mittelpunkt für Customer Relationship-, Human Resources- und Supply Chain-Management. Stuttgart, Germany: Fraunhofer IAO, 2002.

[52] H. Büning, G. Haedrich, H. Kleinert, and A. Kuß, Operationale Verfahren der Markt- und Sozialforschung - Datenerhebung und Datenanalyse [ENGLISHTRANSLATION]. Berlin, Germany: de Gruyter, 1981.

[53] A. Gadeib, "Ansprüche und Entwicklung eines Systems zur Befragung über das World Wide Web" ["ENGLISH TRANSLATION"], in Online Research: Methoden, Anwendungen und Ergebnisse, W. Bandilla, B. Bantinic, and L. Gräf, Eds. Göttingen, Germany: Verlag für Psychologie Dr. C.J. Hogrefe, 1999, pp. 103-111.

[54] B. Bantinic, K. Moser, and B. Puhle, "Der WWW-Fragebogengenerator" ["ENGLISH TRANSLATION"], in Online Research: Methoden, Anwendungen und Ergebnisse, W. Bandilla, B. Bantinic, and L. Gräf, Eds. Göttingen, Germany: Verlag für Psychologie Dr. C.J. Hogrefe, 1999, pp. 93-102.

[55] P. Hauptmanns, "Grenzen und Chancen von quantitativen Befragungen mit Hilfe des Internet" ["ENGLISH TRANSLATION"], in Online Research: Methoden, Anwendungen und Ergebnisse, W. Bandilla, B. Bantinic, and L. Gräf, Eds. Göttingen, Germany: Verlag für Psychologie Dr. C.J. Hogrefe, 1999, pp. 21-38.

[56] W. Voß, Taschenbuch der Statistik [ENGLISH TRANSLATION], 1st ed. München, Germany: Verlag, 2000.

[57] L. Fahrmeir, R. Künstler, I. Pigeot, and G. Tutz, Statistik: Der Weg zur Datenanalyse [ENGLISH TRANSLATION], 2nd ed. Berlin, Heidelberg, Germany: Springer, 1999. 